\title{
MEDIA SOSIAL UNTUK BERDAKWAH DALAM MASYARAKAT VIRTUAL
}

\author{
Muh. Samdzikir \\ Institut Agama Islam Negeri (IAIN) Parepare
}

\begin{abstract}
Abstrak
Kemajuan teknologi saat ini telah berkembang pesat. Lahir dari media baru yang disebut dengan Internet telah membuat orang lebih mudah berkomunikasi tanpa mengetahui hambatan ruang dan waktu. Penggunaannya seperti memberi ruang pada orang, membuatnya lebih mudah dan lebih cepat bagi mereka untuk berinteraksi. Interaksi semacam itu terjalin dalam cara yang baik secara pribadi dan kelompok. Komunikasi kelompok adalah salah satu kebutuhan dasar kita sebagai manusia, sebagai sosial makhluk yang tidak bisa hidup sendiri. Hasil penelitian menunjukkan bahwa alasan dan faktor individu dapat bertahan secara virtual komunitas adalah sebagai alat untuk mengaktualisasikan dan mengembangkan diri, kelompok virtual juga digunakan sebagai pelarian tempat dari kehidupan nyata, kesamaan tujuan kelompok untuk mendorong partisipasi individu, virtual grup digunakan sebagai patokan untuk berperilaku dan sebagai representasi fitur di media sosial sebagai keberadaan diri.
\end{abstract}

Kata Kunci: Masyarakat Virtual, Media Massa,

\section{PENDAHULUAN}

Seiring dengan berjalannya waktu maka tentu saja perkembangan zaman pun akan ikut berkembang. Hal itu, yang menutut masyarakat masyarakat untuk menggunakan virtual seperti saat ini dimana hampir seluruh penduduk bumi enggunakan teknologi. Dengan demikian, Peningkatan pengguna internet serta kemajuan teknologi informasi, menyebabkan perubahan terhadap cara berdakwah. Kemudahan untuk menemui jaringan internet merupakan suatu kelebihan yang dapat menjadikan internet sebagai media atau sebuah sarana alternatif dalam berdakwah. . Hal ini Berawal dari komputer yang digunakan untuk pribadi berubah dan berkembang menjadi jaringan yang lebih luas, tidak saja untuk jaringan lokal tapi sudah menjadi jaringan komputer global dunia yang di kenal dengan internet.

Perilaku pengguna internet menurut APJII, merilis hasil suvei terbaru menunjukan pengguna Internet di Indonesia sudah mencapai 132,7 juta. Perkembangan komunitas virtual saat ini sangat dipengaruhi oleh pertumbuhan dan perkembangan Internet yang sangat pesat. Keadaan tersebut dimanfaatkan banyak kelompok membentuk komunitas virtual secara masif. Banyaknya komunitas virtual 
yang muncul merupakan suatu trend yang memungkinkan manusia berkegiatan di ruang virtual bersama.

Kemajuan teknologi informasi dan pemanfaatan terus meningkat dari waktu ke waktu, yang mana hal ini menyebabkan banyaknya masyarakat virtual khususnya juru dakwah atau para da'i menjadikan teknologi informasi sebagai sarana dakwah karena dengan internet mereka dapat menjangkau seluruh umat Islam yang ada di dunia, tanpa harus secara langsung bertemu dengan mereka. Masyarakat virtual adalah sebuah kehidupan masyarakat manusia yang tidak dapat secara langsung diinderakan melalui penginderaan manusia, namun dapat dirasakan dan disaksikan sebagai sebuah realitas. Kehidupan semacam ini tentu saja bukanlah kehidupan akhirat manusia, namun merupakan sisi lain kehidupan "masyarakat nyata" yang seperti kita ketahui selama ini. Di mana "masyarakat nyata" lebih menekankan pada jalinan kehidupan sosial manusia yang berbasis dan dibangun melalui penginderaan secara langsung. Dalam masyarakat virtual, mendengar ceramah, tausiyah, atau dakwah dari ulamaulama yang ada baik di dalam negeri maupun diluar negeri, serta mencari informasi keagamaan khususnya yang berhubungan dengan dakwah, tidak perlu membutuhkan modal yang banyak.

\section{PEMBAHASAN}

\section{Metode}

Artikel ini disusun melalui beberapa pendeketan dengan melakukan kajian pustaka menghimpun data dari beberapa jurnal terdahulu yang seimbang dengan permasalahan yang ditemukan. Data yang termaktub didalamnya akan kemudian dianalisis secara deskriptif dengan mengemukakan fakta-fakta terkait tentang pentingnya media sosial untuk berdakwah dalam masyarakat virtual ini yang akan di tinjau secara teoritis.

\section{Media Sosial Sebagai Sarana Dakwah}

Istilah sosial media sudah populer digunakan sekitar tahun 1994 (Bercovici, 2010). Dalam tujuan terbentuknya, sosial media dapat membantu kita menjadi manusia yang lebih baik. Platform media sosial pada umumnya menawarkan nilainilai sosial. Kemampuan untuk berbagi dan membuat dunia yang luas seakan terhubung, menjadi nilai sosial didalamnya. Setiap bulan hampir dari 1.35 miliyar orang login di sosial media, yang berarti satu dari lima orang di dunia ini memiliki akun sosial media (Nancy Baim, 2015). Interaksi sosial adalah dasar dari sifat manusiawi kita. Ini adalah cara untuk membuat dunia kita sendiri. Media komunikasi sangat penting dalam membentuk masa depan kita. Motif dari pengguna sosial media beragam mulai dari minat, pekerjaan, hobi, keterampilan, diskusi, kelompok belajar, sumber informasi dan lain-lain. Kesamaan minat mereka mendorong terbentuknya individuindividu dalam 
satu kelompok utuh, hingga membuat komunitas grup virtual untuk mempermudah mobilitas bersama.

Dengan adanya peningkatan pengguna internet serta kemajuan teknologi informasi, menyebabkan perubahan terhadap cara berdakwah. Saat ini para da'i atau juru dakwah mulai memanfaatkan kemajuan teknologi informasi dalam penyampaian dakwahnya. Dengan penggunaan teknologi informasi, kegiatan dakwah bisa dilakukan lebih insentif dan menjangkau jaringan yang lebih luas. Berdasarkan pernyataan Kemkominfo, 95 persen dari 63 juta penduduk Indonesia menggunakan internet untuk mengakses jejaring sosial. Oleh karen itu penggunaan internet sebagai media dakwah bisa menjadi salah satu alternatif yang efektif dalam melakukan dakwah Islam.

\section{Pengertian Dakwah}

Dakwah secara etimologis berasal dari bahasa Arab da'a-yad'u yang berarti memanggil atau menyeru, mengajak atau menngundang. Secara harfiyah dakwah merupakan mashdar dari fi'il (kata kerja) da'a dengan arti ajakan, seruan, undangan, dan panggilan. Warson Munawir menyebutkan bahwa dakwah berarti memanggil (to call), mengundang (to invite), mengajak (to summon), menyeru (to propose), mendorong (to urge), dan memohon (to pray). Sedangkan dakwah menurut Al-Quran diartikan sebagai perintah menyeru manusia ke jalan Tuhan dengan cara hikmah dan pelajaran yang baik dengan berbagai metode dan pendekatan. dakwah merupakan sebuah seruan atau ajakan menuju Allah yang mana seruan tersebut berisi ajakan amar ma'ruf nahi mungkar yang dilakukan dengan cara-cara yang baik, dan bertujuan agar objek dakwah mencapai keberuntungan baik itu berupa kebahagiaan di dunia maupun di akhirat.

Selain dakwah bertujuan untuk mengajak dan menasehati, dakwah memiliki peran sebagai faktor penyeimbang kehidupan manusia untuk tidak hanya berhikmat pada kehidupan duniawi yang kian dimegahkan oleh kemajuan teknologi canggih, akan tetapi juga diperlukan mengevaluasi diri untuk terus menyeimbangkannya dengan kehidupan ruhaniah (akhirat). Menurut Al-Ghazali dalam Pia Khoirotun Nisa disebutkan konsep dakwah 'amar ma'rūf nahi mungkar merupakan bagian yang tak terpisahkan satu dari yang lainnya, meliputi segala aspek kehidupan manusia, begitu juga sebaliknya para pendukung perbuatan mungkar dan yang menghalangi ma'rūf akan menggunakan segala jalur kehidupan. 'Amar ma'rūf nahi mungkar merupakan sarana yang dapat dijadikan kegiatan dakwah Islamiyah. Dakwah tidak akan tumbuh dan berkembang tanpa 'amar ma'rūf nahi mungkar (Nisa, 2018: 249). Karenanya, betapapun berkembangan teknologi informasi dan komunikasi yang dipergunakan manusia, maka kebutuhan dakwah akan terus relevan untuk mengingatkan kepada kebenaran yang mutlak. Seiring dengan perkembangan zaman, kegiatan dakwah tidak hanya dapat dilakukan dalam satu majelis khusus dan disampaikan secara manual atau 
bertatap muka. Namun kini dapat dilakukan di manapun dan kapanpun, meski tanpa bertatap muka. Misalnya dengan keberadaan internet yang merupakan produk kemajuan zaman,maka dakwah dapat dilakukan secara mudah dan meluas. Internet dapat dipergunakan sebagai salah satu alternatif cara berdakwah yang strategis dan dimungkinkan terciptanya komunikasi yang lebih baik antar umat yang semakin menglobal ini. Sebagian orang muslim mengakui manakala dakwah dilakukan melalui media virtual atau yang dikenal dengan dunia maya, daya jangkau penyiaran Islam akan lebih efektif.Penyiaran dakwah melalui media nantinya akan menjadi titik tolak untuk menemukan bentuk ideal suatu sarana dakwah yang lebih tepat untuk dikembangkan di masa kini dan masa depan. Keberadaan internet yang sangat tinggi nilai kegunaannya ini, tentu akan memiliki nilai tersendiri manakala dimanfaatkan dalam kegiatan dakwah dengan strategi manajemen yang lebih mampu menjangkau mad'u (penerima dakwah) yang lebih luas.

\section{Berdakwah Dalam Masyarakat virtual}

Internet menyimpan sejuta potensi untuk dimanfaatkan. Fungsinya berawal dari media informasi yang statis hingga menjelma menjadi dunia virtual, dunia yang tidak nyata secara fisik, tetapi di dalamnya justru menyimpan semua kegiatan yang ada di kehidupan nyata, mulai dari belajar, berbelanja, berjualan,hingga kegiatan yang sulit ditemukan dalam dunia nyata.Saat ini, banyak di kalangan para da'i(pendakwah)yang menyampaikan dakwahnya melalui media sosial dan itu merupakan peluang yang sangat besar untuk menarik perhatian masyakat modern sebagai objek kegiatan dakwah. maka dengan hadirnya teknologi canggih ini para da'i semakin mudah untuk berdakwah kapan saja dan di mana saja, tanpa terikat oleh ruang dan waktu. Dengan keberadaan internet yang membuat dunia terasa semakin sempit, maka di satu sisi peluang dakwah kianterbuka untuk dilaksanakan secara luas dan mendunia. Namun di sisi lain tantangan yang di hadapi para da'i pun memang tidak semakin ringan, kian hari kian berat dan kian komplek. Oleh karena itu, para da'i dituntut untuk mengantisipasi diri agar supaya tidak terlalu terlena dengan keberadaan media yang begitu mudah tersebut. Lantas, bagaimana peran da'i yang sebenarnya? Seorang da'i diperlukan lebih menguasai media yang terus berkembang tiada henti ini, namun ia juga harus membatasi diri di dalam menggunakannya agar supaya tidak terjerumus ke dalam hegemoni media yang sedang berkembang.

Ada beberapa langkah yang harus dipahami oleh para da'i saat berdakwah melalui media di eramodern ini antara lain;

Pertama; Memiliki kemampuan retorika. Kemampuan retorika bukan hanya berkenaan dengan kemampuan mengekspresikan materi dakwah secara verbal, namun juga menyangkut style atau gaya khas da'i dalam menyampaikan materi dakwah. Style 
tersebut tidak perlu dibuat-buat, namun perlu dilatih secara praktis dan sesuai dengan kepribadian da'i, sehingga da'i merasa nyaman menggunakannya.

Kedua; Memiliki pengetahuan dasar tentang psikologi individu serta sosial. Ilmu psikologi merupakan ilmu pendamping dalam membantu da'i menentukan karakteristik, kecenderungan serta kondisi mad'u, sehingga mampu menentukan materi dakwah dan cara penyampaiannya secara tepat. Ilmu ini dapat dipelajari dengan mengikuti berbagai pelatihan atau secara otodidak lewat membaca buku serta berbagi pengalaman sesama da'i.

Ketiga; Memiliki kemampuan untuk memanfaatkan berbagai media untuk kegiatan dakwah. Sudah bukan zamannya lagi seorang da'i gagap teknologi. Perkembangan media elektronik dan sosial saat ini membuat arus informasi mengalir begitu deras kepada masyarakat tanpa terbendung. Sesudah melihat banyak hal baru, tentunya mad'uakan kehilangan minat ketika mendengarkan dakwah yang disampaikan ala kadarnya. Dibutuhkan kemasan yang menarik untuk membangkitkan kembali minat mad'u. Da'i dapat memanfaatkan media sosial untuk mengemas materi dakwah menjadi lebih hidup, misalnya dengan menampilkan cuplikan video, foto atau gambar yang dapat membantu mad'u memahami materi dakwah (Risdiana, 2014: 443).

Hal ini menjadi tantangan bagi seorang da'i untuk menyuguhkan pesanpesan dakwah yang variatif dan semenarik mungkin supaya tidak kehilangan simpati dan perhatian dari mad'u. Tantangan dari mad'u yang dihadapi seorang da'ipun sekarang lebih besar dari sebelumnya, bisa jadi mad'u yang dihadapi lebih cerdas dari da'inya, karena semua pengetahuan sudah siap tersaji di internet. Menurut Andi Faisal Bakti untuk mengimbangi derasnya informasi dan teknologi dakwah harus dikemas dengan cara yang menarik dan tampil secara aktual, faktual, dan kontekstual. Aktual berarti dapat memecahkan masalah yang kekinian dan hangat di kalangan masyarakat. Faktual berarti kongkret dan nyata, sedangkan kontekstual dalam arti relevan dan menyangkut problem yang sedang dihadapi oleh masyarakat (Bakti \& Meidasari, 2014: 21-44). 


\section{PENUTUP}

\section{Kesimpulan}

Secara garis besar dakwah berarti mengajak seseorang atau masyarakat untuk melakukan sesuatu dan meninggalkan sesuatu lainnya, yang harus dilakukan dengan menggunakan suatu media. Hafi Anshori menyebut dakwah adalah proses penyelenggaraan suatu usaha mengajak orang untuk beriman dan menaati Allah Subhanahu wa Ta'ala, amar ma'ruf, perbaikan dan pembangunan masyarakat dannahi mungkar yang dilakukan dengan sengaja dan sadar untuk mencapai tujuan tertentu, yaitu kebahagiaan dan kesejahteraan hidup yang diridhoi Allah Subhanahu wa Ta'ala. Pada intinya konsep dakwah terdapat pada 'amar ma'ruf dan nahi mungkar.

\section{Daftar Pustaka}

Bakti. A.F \& Meidasari, V. E. 2014. Trendsetter Komunikasi di Era Digital: Tantangan dan Peluang Pendidikan Komunikasi dan Penyiaran Islam. Jurnal Komunikasi Islam, 4(1): 21-44. (http://jki.uinsby.ac.id/index.php/jki/article/view/35) diakses 23 JULI 2020.

Nisa, Komunikasi, Pia Khoirotun. 2018. Dakwah Imam Al-Ghazali Dalam Kitab Iḥyā 'Ulumiddīn. Wardah: Jurnal Dakwah Dan Kemasyarakatan, (online), 4 (1): 51-74, (http://jurnal.stitalamin.ac.id/index.php/alamin/article/view/11) diakses 23 JULI 2020.

Risdiana, Aris. 2014. Tranformasi Peran Da'i dalam menjawab peluang dan tantangan; studi terhadap manajemen SDM, Jurnal Dakwah, (online), 15(2):433451(http://ejournal.uinsuka.ac.id/dakwah/jurnaldakwah/article/view/315) diakses 23 JULI 2020. 